\title{
Spatiotemporal Variation of Bacterial Assemblages in a Shallow Subtropical Coastal Lagoon in Southern Brazil
}

\author{
Maria Luiza Schmitz Fontes • Paulo C. Abreu
}

Published online: 28 May 2009

(C) Springer Science + Business Media, LLC 2009

Erratum to: Microb Ecol

DOI 10.1007/s00248-009-9454-z

In the original version of this article, the second to the last sentence of the Abstract section was incomplete, the words "The stratified" are missing. The sentence should read: "The stratified area revealed a singular temporal pattern with hypoxic bottom waters in winter and oxygen-rich waters appearing in summer related with the availability of light and predominant microbes."

The online version of the original article can be found under http://dx. doi.org/10.1007/s00248-009-9454-z.

M. L. S. Fontes $(\bowtie)$

Post-Graduation Course on Biological Oceanography,

Institute of Oceanography,

Federal University of Rio Grande (FURG),

Av. Itália km 08 ,

Rio Grande, RS 96201-900, Brazil

e-mail: luaondas@yahoo.com.br

\section{P. C. Abreu}

Aquaculture and Biotechnology Division, Institute of Oceanography,

Federal University of Rio Grande (FURG),

Av. Itália km 08 ,

Rio Grande, RS 96201-900, Brazil 